\title{
Standardization of Rapid Multiplication Technique (RMT) in Cassava (Manihot esculenta Crantz.)
}

\author{
L. Pugalendhi ${ }^{1}$ and M. Velmurugan ${ }^{2 *}$ \\ ${ }^{1}$ Horticulture, HC\&RI, TNAU Coimbatore-641003, TN, India \\ ${ }^{2}$ Department of Floriculture and Landscaping, HC\&RI, TNAU Coimbatore-641003, TN, India \\ *Corresponding author
}

\begin{abstract}
A B S T R A C T
Cassava (Manihot esculenta Crantz.) is an important tuber cultivated in India. Cassava is vegetatively propagated through stem cuttings (setts). A mature plant with two stems will give about 12 to 20 normal sized $(20 \mathrm{~cm})$ setts after one year. Farmers are practicing 8-10 $\mathrm{cm}$ long cuttings from the mature part of stem and planted in vertical position in nursery bed at closer spacing of $5 \mathrm{~cm}$. Under conventional system of propagation, 1250 to 1500 stems are required for planting one hectare of area. Cassava is highly susceptible to cassava mosaic disease (CMD) and disease spreads through infected setts and transmitted by white flies. In the present investigation, normal set, mini sett and chip bud are planted in different growing media viz., cocopeat, vermicompost and pot mixture with addition of Pseudomonas. The results revealed that the minimum number of days (4.60) required for sprouting, maximum sprouting percentage (97.50), lengthiest roots $(29.80 \mathrm{~cm})$ and maximum number of roots (10.00) was recorded in Cocopeat + Chip bud and the minimum sprouting percentage (82.10) was observed in Cocopeat + Pseudomonas + Normal sett $\left(\mathrm{M}_{1} \mathrm{~S}_{1}\right)$. In this new rapid multiplication technique, tagging disease free plants and using them for propagation offers reliable solution to manage the disease as lesser quantity of setts are required for planting. In addition to the above, the planting materials of newly released varieties can be easily multiplied in large scale and supplied to the farmers.
\end{abstract}

\section{Keywords}

Cassava, Rapid multiplication technique, Sprouting, Tuber

\section{Article Info}

Accepted:

26 April 2020

Available Online:

10 May 2020

\section{Introduction}

Cassava is an important tuber crop cultivated in India. Tubers are highly rich in starch and mainly used for preparation of sago. In addition to the above, it is used as raw material for multifarious industrial uses viz., dextrin, glucose, core binder, stabilizer, adhesives, sizing yarns, as thickener for printing clothes and etc. Nutritionally, roots and tubers have a great potential to provide economical sources of dietary energy, in the form of carbohydrates (Chandrasekara and Kumar, 2016). The energy from tubers is about one-third of that of an equivalent weight of rice or wheat due to high moisture content of tubers. In India, it is cultivated mainly in Kerala, Tamil Nadu, Karnataka and 
Andhra Pradesh. Kerala and Tamil Nadu account for about $80 \%$ of the total acreage of the crop in India. During 2018-19, cassava is cultivated in an area of 1.73 lakh hectares with the production of 49.50 lakh tonnes (NHB, 2019). Cassava is vegetatively propagated through stem cuttings (setts). A mature plant with two stems will give about 12 to 20 normal sized $(20 \mathrm{~cm})$ setts after one year i.e the propagation rate is 12 to 20 times per year. The use of shorter cuttings $(12 \mathrm{~cm}$ long) permits a higher rate of multiplication with a given amount of planting material; but short cuttings are difficult to establish in the field under rainfed conditions; if soil moisture at the time of planting is not favourable.

Commercially, farmers are practicing $8-10 \mathrm{~cm}$ long cuttings from the mature part of stem and planted in vertical position in specially prepared nursery bed at closer spacing of 5 $\mathrm{cm}$. The setts are prepared with sett cutter and dipped in Carbendazim (2 g/litre of water) and Dimethoate ( $2 \mathrm{ml} /$ litre of water). The bed is constantly pot watered daily to moisten the soil. Three weeks after planting, the setts are ready for transplanting. At CTCRI, mini sett propagation technique has been standardized using 2-3 node cuttings, propagated in moist chamber which was found to be most efficient. This can give 640 plants from a single plant in one year, instead of average 10 plants from a single cassava stem. In this technique though the crop establishment is fairly good enough $(80-90 \%)$ still it needs gap filling. The rooted cuttings cannot be transported from one place to other place because of bare roots.

In seed propagated vegetables, quality seedlings are produced and distributed through protray system. Protray system is the most efficient system in developing uniform sized disease free seedlings materials. It has advantageous than raised bed system viz., precised use of seeds, production of pest and disease free seedlings, uniform growth and seedling establishment due to the presence of ball of earth during transplantation and etc. Seedling production in protrays can easily be monitored and transported to the site/field, where the planting is taken up. This system of propagation has a great potential in vegetatively propagated crops like cassava. Vivek and Duraisamy (2017) reported that the maximum growth parameters of Tomato such as shoot length, root length, stem diameter and no. of leaves $(89.3 \mathrm{~mm}, 37.9 \mathrm{~mm}, 1.77$ $\mathrm{mm}$ and 4) were observed at 30 days aged seedlings with coirpith media. The minimum growth parameters $(82.9 \mathrm{~mm}, 34 \mathrm{~mm}, 1.08$ $\mathrm{mm}$ and 3 respectively) were observed with vermicompost for the same day of aged seedlings. The maximum germination was found to be 99 per cent with coir pith and the minimum was 87 per cent in vermicompost. Apart from the above, the newly released varieties have to be produced in larger scale for distribution to farmers. Cassava is highly susceptible to cassava mosaic disease (CMD) and disease spreads through infected setts and subsequently transmitted by white flies. In the new rapid multiplication technique, tagging disease free plants and using them for propagation offers reliable solution to manage the disease as lesser quantity of setts are only required under Rapid Multiplication Technique (RMT) of cassava. Considering the bottle necks, the experiment was formulated to standardize a rapid method of propagation technique in cassava using protrays system.

\section{Materials and Methods}

The experiment was conducted for three years at TNAU, Tapioca and Castor Research Station, Yethapur, Salem district, Tamil Nadu. The cassava setts of variety YTP 1 were used for the Rapid Multiplication Technique (RMT) using protray system with different propagation media. The experiment was designed in split plot design with four 
replications and the main plot consists of treatments viz., Cocopeat + Pseudomonas $\left(\mathrm{M}_{1}\right)$, Vermicompost + Pseudomonas $\left(\mathrm{M}_{2}\right)$ and Pot mixture + Pseudomonas $\left(\mathrm{M}_{3}\right)$. In the main plot treatments, Pseudomonas @ $1 \mathrm{~kg}$ is mixed and approximately $1.2 \mathrm{Kg}$ of the media is filled in each protray. The subplot consists of Normal sett $\left(S_{1}\right)$, Mini sett $\left(S_{2}\right)$ and Chip bud $\left(S_{3}\right)$. Commercially, the farmers are adopting normal setts which consist of eight to ten nodal cuttings and CTCRI, Thiruvananthapuram has recommended mini sett propagation technique using 2-3 node cuttings. In the present investigation, chip bud consists of one to two nodal cuttings were prepared and planted in protrays until complete establishment. The planting materials were planted in Cocopeat + Pseudomonas, Vermicompost + Pseudomonas and Pot mixture + Pseudomonas and watering is done on daily basis.

The seedlings produced in various treatments were evaluated for number of days taken for sprouting, sprouting $(\%)$, length of roots $(\mathrm{cm})$ and number of roots. The statistical analysis was done by adopting the standard procedures of Panse and Sukhatme (1985). The critical difference was worked out at five per cent $(0.05)$ probability. The pooled mean analysis was carried out with AGRES software package and MS Excel spreadsheet.

\section{Results and Discussion}

In this experiment, the normal sett used for planting by farmers is $12 \mathrm{~cm}$ long with eight to ten nodes. At CTCRI, mini sett with 2-3 node cuttings is used for propagation of cassava. In this experiment, chip buds with one to two nodal cuttings are used for propagation in protray system with different media viz., potting mixture, vermicompost and coir compost.
Among the treatments, the maximum number of days (11.10) for sprouting of buds is recorded in Normal sett $\left(\mathrm{M}_{2} \mathrm{~S}_{1}\right)$ and the minimum number of days (4.60) required for sprouting is recorded in Cocopeat + Pseudomonas + Chip bud $\left(\mathrm{M}_{1} \mathrm{~S}_{3}\right)$. The pot mixture + Pseudomonas + normal sett $\left(\mathrm{M}_{3} \mathrm{~S}_{3}\right)$ required 8.0 days for sprouting of setts, sprouting per cent (83.10), length of roots $(21.90 \mathrm{~cm})$ and number of roots $(5.80)$.

The maximum sprouting percentage (97.50) was recorded in Cocopeat + Pseudomonas + Chip bud $\left(\mathrm{M}_{1} \mathrm{~S}_{3}\right)$ and the minimum sprouting percentage (82.10) was observed in Cocopeat + Pseudomonas + Normal sett. The lengthiest roots $(29.80 \mathrm{~cm})$ and maximum number of roots (10.00) was recorded in Cocopeat + Pseudomonas + Chip bud $\left(\mathrm{M}_{1} \mathrm{~S}_{3}\right)$. However the shorter roots $(18.00 \mathrm{~cm})$ and lesser number of roots (6.30) was exhibited in Pot mixture + Pseudomonas + Mini sett $\left(\mathrm{M}_{3} \mathrm{~S}_{2}\right)$ (Table.1). The better performance of planting materials in cocopeat may be due to the reason that it had wider $\mathrm{CN}$ ratio, higher percentage of lignin and hemicellulose. More over digested coirpith compost by inherent nature helps to retain moisture for long time which might have favoured the shorter time for sprouting, maximum sprouting percentage, length of roots and number of roots.

The present investigation is in agreement with the findings of Hayman (1975), Gaur (1989), Abad et al., (2002), Atif et al., (2016) and Prasth et al., (2016). In addition to the above, Pseudomonas might have protected the cut ends of planting materials from harmful pathogens which in turn promoted the success rate of chip bud under protray system. The above technology will be highly useful for rapid multiplication and spreading of newly released varieties besides the supply of disease free planting materials. 
Table.1 Pooled mean analysis for the standardization of media for propagation of cassava through protray system

\begin{tabular}{|c|c|c|c|c|c|c|c|c|c|c|c|c|c|c|c|c|}
\hline \multirow[t]{2}{*}{ Treatments } & \multicolumn{4}{|c|}{$\begin{array}{c}\text { Number of days taken for } \\
\text { sprouting }\end{array}$} & \multicolumn{4}{|c|}{ Sprouting (\%) } & \multicolumn{4}{|c|}{ Length of roots $(\mathrm{cm})$} & \multicolumn{4}{|c|}{ No. of roots } \\
\hline & $\begin{array}{c}1^{\text {St }} \\
\text { year }\end{array}$ & $\begin{array}{c}2^{\text {nd }} \\
\text { year }\end{array}$ & $\begin{array}{c}3^{\text {rd }} \\
\text { year }\end{array}$ & $\begin{array}{c}\text { Pooled } \\
\text { mean }\end{array}$ & $\begin{array}{c}1^{\text {St }} \\
\text { year }\end{array}$ & $\begin{array}{c}2^{\text {nd }} \\
\text { year }\end{array}$ & $\begin{array}{c}3^{\text {rd }} \\
\text { year }\end{array}$ & $\begin{array}{c}\text { Pooled } \\
\text { mean }\end{array}$ & $\begin{array}{c}1^{\text {St }} \\
\text { year }\end{array}$ & $\begin{array}{c}2^{\text {nd }} \\
\text { year }\end{array}$ & $\begin{array}{c}3^{\text {rd }} \\
\text { year }\end{array}$ & $\begin{array}{c}\text { Pooled } \\
\text { mean }\end{array}$ & $\begin{array}{c}1^{\text {St }} \\
\text { year }\end{array}$ & $\begin{array}{c}2^{\text {nd }} \\
\text { year }\end{array}$ & $\begin{array}{c}3^{\text {rd }} \\
\text { year }\end{array}$ & $\begin{array}{c}\text { Pooled } \\
\text { mean }\end{array}$ \\
\hline $\mathbf{M}_{1} \mathbf{S}_{1}$ & 9.3 & 8.3 & 8.3 & 8.0 & 91.0 & 85.2 & 73.2 & 83.10 & 21.1 & 26.1 & 18.4 & 21.9 & 6.5 & 6.3 & 4.6 & 5.8 \\
\hline $\mathbf{M}_{1} \mathbf{S}_{2}$ & 7.5 & 7.7 & 8.2 & 7.8 & 91.6 & 84.7 & 73.2 & 83.20 & 22.7 & 24.5 & 23.5 & 23.5 & 8.0 & 6.3 & 6.0 & 6.8 \\
\hline $\mathbf{M}_{1} \mathbf{S}_{3}$ & 4.7 & 4.7 & 4.5 & 4.6 & 99.3 & 96.7 & 96.4 & 97.50 & 35.3 & 31.0 & 23.2 & 29.8 & 8.5 & 12.0 & 9.6 & 10.0 \\
\hline $\mathbf{M}_{2} \mathbf{S}_{1}$ & 11.0 & 11.0 & 11.2 & 11.1 & 90.5 & 89.1 & 85.2 & 88.30 & 18.9 & 23.4 & 15.7 & 19.3 & 7.5 & 7.0 & 6.6 & 7.0 \\
\hline $\mathbf{M}_{2} \mathbf{S}_{2}$ & 9.0 & 8.7 & 9.0 & 8.9 & 91.5 & 88.7 & 83.2 & 87.80 & 17.0 & 26.1 & 16.5 & 19.9 & 8.0 & 7.0 & 6.4 & 7.1 \\
\hline $\mathbf{M}_{2} \mathbf{S}_{3}$ & 5.5 & 5.3 & 5.9 & 5.6 & 98.0 & 92.7 & 94.5 & 95.10 & 29.3 & 29.0 & 20.8 & 26.4 & 8.0 & 9.7 & 8.2 & 8.6 \\
\hline $\mathbf{M}_{3} \mathbf{S}_{1}$ & 13.3 & 12.3 & 13.9 & 13.2 & 89.8 & 85.6 & 80.4 & 85.30 & 26.4 & 25.7 & 18.6 & 23.6 & 6.8 & 6.3 & 6.5 & 6.5 \\
\hline $\mathbf{M}_{3} \mathbf{S}_{2}$ & 9.0 & 9.3 & 10.2 & 9.5 & 91.8 & 83.1 & 84.5 & 86.50 & 16.6 & 25.8 & 11.6 & 18.0 & 6.5 & 7.0 & 5.3 & 6.3 \\
\hline $\mathbf{M}_{\mathbf{3}} \mathbf{S}_{\mathbf{3}}$ & 5.5 & 5.7 & 6.0 & 5.7 & 98.0 & 87.1 & 96.4 & 93.80 & 23.1 & 21.4 & 16.0 & 20.2 & 8.8 & 8.3 & 7.8 & 8.3 \\
\hline CD (0.05) & 4.20 & 1.34 & 1.29 & 1.30 & 0.93 & 1.82 & 1.79 & 2.01 & 0.81 & 2.44 & 2.9 & 2.61 & 1.12 & 0.83 & 1.27 & 1.07 \\
\hline SEd & 2.05 & 0.64 & 0.64 & 0.65 & 0.46 & 0.86 & 0.89 & 1.00 & 0.39 & 1.15 & 1.45 & 1.31 & 0.52 & 0.39 & 0.63 & 0.53 \\
\hline
\end{tabular}




\section{References}

Abad M, P. Noguera, R. Puchades, A. Maquieira and V. Noguera. 2002. Physico-chemical and chemical properties of some coconut dusts for use as a peat substitute for containerized ornamental plants. Bio-resource Technology. 82(3), 241- 245.

Atif, M. J., G. Jellani, M. H. A. Malik, N. Saleem, H. Ullah, M. Z. Khanand S. Ikram. 2016. Different Growth Media Effect the Germination and Growth of Tomato Seedlings. Science, Technology and Development. 35(3), 123-127.

Chandrasekara, A., and T.J. Kumar. 2016. Roots and Tuber Crops as Functional Foods: A Review on Phytochemical Constituents and Their Potential Health Benefits. International J. Food Science. Pp.1-16.

Gaur, A.C. and A.R. Alagawadi. 1989. Interaction of nitrogen fixing and phosphate solubilizing microorganisms on crop productivity. Plant Microbe Interactions. Proc: Focal Theme Sym. Botany Section, ISCA, Bangalore. pp.35-46, India.

Hayman, D.S. 1975. Phosphorus cycling by soil microorganism and plant roots. In Soil Microbiology: A critical review. Ed. N.Walter, Butterworths, London and Boston, 67-92.

National Horticultural Board, 2019. Area and Production of Horticulture Crops - All India. Pp.1-3.

Prasath, D., K. Kandiannan, V. Srinivasan, M. Anandaraj. 2016. Improved propagation techniques in Ginger and Black Pepper. Spice India, January issue, Pp.27-29.

Vivek, P. and V.M. Duraisamy. 2017. Study of growth parameters and germination on tomato seedlings with different growth media. Intl. J. Agrl. Sci. and Res., 7(3): 461-470.

\section{How to cite this article:}

Pugalendhi, L. and Velmurugan, M. 2020. Standardization of Rapid Multiplication Technique (RMT) in Cassava (Manihot esculenta Crantz.). Int.J.Curr.Microbiol.App.Sci. 9(05): 30213025. doi: https://doi.org/10.20546/ijcmas.2020.905.359 